\title{
Evaluasi In Vitro Silase Sinambung Sorgum Varietas Samurai 2 yang Mengandung Probiotic BIOS K2 dalam Cairan Rumen Kerbau
}

\section{In Vitro Evaluation of Continuous Silage of Sorghum Varieties Samurai 2 Containing Probiotic of BIOS K2 in Rumen Fluid of Buffalo}

\author{
Shafa Imanda ${ }^{1}$, Yunus Effendi ${ }^{1}$, Sihono ${ }^{2}$ dan Irawan Sugoro ${ }^{1,2}$ \\ ${ }^{1}$ Prodi Biologi Fakultas Sains dan Teknologi - Universitas Al Azhar Indonesia \\ Komplek Masjid Agung Al Azhar, Jakarta 12110 \\ ${ }^{2}$ Pusat Aplikasi Isotop dan Radiasi, BATAN \\ Jl. Lebak Bulus Raya No. 49, Jakarta 12440 \\ E-mail: info@uai.ac.id
}

Diterima 26-11-2015; Diterima dengan revisi 21-12-2015; Disetujui 29-02-2016

\begin{abstract}
ABSTRAK
Evaluasi In Vitro Silase Sinambung Sorgum Varietas Samurai 2 yang Mengandung Probiotik BIOS K2 dalam Cairan Rumen Kerbau. Kebutuhan pakan hijauan ternak ruminansia dapat ditingkatkan kualitasnya dengan pembuatan silase. Salah satu teknik silase yang dikembangkan adalah silase sinambung, yaitu suatu teknologi modifikasi pembuatan silase dengan waktu fermentasi yang lebih singkat akibat pemberian bibit silase pada saat awal pembuatannya. Peningkatan kualitas silase dapat dilakukan dengan menambah suplemen berupa probiotik seperti BIOS K2. Tujuan dari penelitian ini adalah untuk mengevaluasi pakan silase sinambung hijauan sorghum varietas Samurai 2 yang mengandung probiotik BIOS K2. Evaluasi pakan dilakukan dengan metode in vitro Hohenheim gas test menggunakan inokulum cairan rumen dari kerbau berfistula yang diinkubasi selama 24 jam pada suhu $39^{\circ} \mathrm{C}$. Perlakuan terdiri dari pakan A (silase sorgum 21 hari), B (silase sinambung sorghum 3 hari), dan C (silase sinambung sorgum 7 hari). Parameter yang diuji adalah konsentrasi amonia, volatile fatty acids (VFA), sintesis protein mikroba (bakteri dan protozoa), degradasi bahan organik (\%DBO), konsentrasi gas karbondioksida $\left(\mathrm{CO}_{2}\right)$ dan metana $\left(\mathrm{CH}_{4}\right)$. Data hasil perlakuan dianalisis dengan menggunakan rancangan acak lengkap. Hasil pengujian menunjukkan bahwa adanya pengaruh yang signifikan perlakuan pakan terhadap konsentrasi amonia, konsentrasi VFA, sintesis protein mikroba dan \%DBO, sedangkan untuk konsentrasi gas $\mathrm{CO}_{2}$ dan $\mathrm{CH}_{4}$ tidak ada pengaruh. Perlakuan pakan $\mathrm{C}$ menghasilkan konsentrasi amonia, VFA dan sintesis protein bakteri berturut-turut sebesar $0,44 \mathrm{mg} / \mathrm{ml} ; 0,89 \mathrm{mg} / \mathrm{ml}$; dan $5,18 \mathrm{mg} / \mathrm{ml} / \mathrm{jam}$, lebih tinggi dibandingkan dengan perlakuan A dan B. \%DBO tertinggi terjadi pada perlakuan A sebesar $47,30 \%$, sedangkan B dan C sebesar 25,18 dan $37,15 \%$. Sintesis protein mikroba protozoa tertinggi terjadi pada perlakuan A dan B sebesar 2,62 $\mathrm{mg} / \mathrm{ml} / \mathrm{jam}$, sedangkan perlakuan C sebesar 2,55 mg/ml/jam. Disimpulkan dari percobaan ini bahwa pakan silase sinambung sorgum varitetas Samurai 2 dengan lama inkubasi selama 7 hari (C) memiliki kualitas yang lebih baik dibandingkan dengan silase sorgum yang diinkubasi 21 hari (A).
\end{abstract}

Kata Kunci : Silase, silase sinambung, sorgum varietas Samurai 2, in vitro, probiotik BIOS K2

\section{ABSTRACT}

In Vitro Evaluation of Continuous Silage of Sorghum Varieties Samurai 2 Containing Probiotic of BIOS K2 in Rumen Fluid of Buffalo. Ruminant forage needs could be enhanced by making silage. One of develop techniques was a continuous silage that is a modification technology of making silage by reducing the fermentation time through the addition of seeds inoculum at the beginning of the forages production. The quality of silage 
could be improved by adding a probiotic supplement such as BIOS K2.Forage that has a potency as silage is sorghum var. Samurai 2. The aim of this study was to evaluate the continuous silage of sorghum var. Samurai 2 that contained probiotics BIOS K2. Evaluation of sample used in vitro Hoheinheim gas test method by using buffalo rumen fluid which was incubated for 24 hours at $39^{\circ} \mathrm{C}$. Treatments were A (silage sorghum 21 days), B (continuous sorghum silage 3 days), and $\mathrm{C}$ (continuous silage sorghum 7 days). The parameters tested were degradation of organic matter (\%DOM), ammonia, volatile fatty acids (VFA), the levels of carbon dioxide $\left(\mathrm{CO}_{2}\right)$ and methane $\left(\mathrm{CH}_{4}\right)$, as well as protein synthesis microbes (bacteria and protozoa). The analysis indicated there was a significant effect in thefeed treatment to ammonia concentration, the concentration of VFA, microbial protein synthesis and \% DOM, while there were no effect in levels of $\mathrm{CO}_{2}$ and $\mathrm{CH}_{4}$. Treatment of feed $\mathrm{C}$ produced ammonia, VFA and bacterial protein synthesis respectively of $0.44 / \mathrm{ml} ; 0.89 \mathrm{mg} / \mathrm{ml}$; and $5.18 \mathrm{mg} . \mathrm{ml}^{-}$ ${ }^{1}$ hour $^{-1}$, higher than treatment $\mathrm{A}$ and $\mathrm{B}$. The treatment $\mathrm{A}$ had the highest DOM percentage i.e. $47.30 \%$, while B and C i.e. 25.18 and $37.15 \%$ respectively. Treatment A and B had higher activity of protozoa microbial protein synthesis, respectively of $2.62 \mathrm{mg} \cdot \mathrm{ml}^{-1}$ hour $^{-1}$ than treatment $\mathrm{C}$ of $2.55 \mathrm{mg} \cdot \mathrm{ml}^{-1}$ hour $^{-1}$. It could be concluded that a continuous feed silage sorghum var. Samurai 2 with time of incubation for 7 days $(\mathrm{C})$ has a better quality than sorghum silage with 21 days incubation (A).

Keywords : Silage, continuous silage, Sorghum var. Samurai 2, in vitro, probiotic of BIOS K2

\section{PENDAHULUAN}

Produktivitas ternak ruminansia dapat ditingkatkan dengan memperhatikan aspek nutrisi, kesehatan, reproduksi, dan manajemen ternak [1]. Kendala utama peternak yaitu produksi pakan tidak dapat dipenuhi untuk mencukupi kebutuhan ternak. Oleh karena itu, peternak dapat menggunakan teknik silase untuk menjadikan pakan menjadi tahan lama, namun dengan kandungan nutrisi yang tidak hilang serta dapat memenuhi kebutuhan pakan bagi ternak secara berkelanjutan [2].

Teknik produksi silase yang sedang dikembangkan saat ini adalah silase sinambung. Silase yang telah terbentuk akan disisakan untuk digunakan sebagai bibit saat produksi silase sinambung. Keunggulan teknik silase sinambung adalah waktu fermentasi yang terjadi dapat dilakukan dengan singkat dibandingkan dengan teknik silase pada umumnya yang di atas 21 hari [3]. Hasil analisis protein dan lemak silase sinambung jagung yang diinkubasi 7 dan 14 hari menunjukkan tidak ada perbedaan nyata dengan silase biasa yang diinkubasi selama 21 hari atau yang dijadikan bibit [4].

Bahan baku yang dapat digunakan untuk pembuatan silase salah satunya yakni tanaman pertanian seperti sorgum. Sorgum merupakan tanaman yang mempunyai banyak kegunaan. Hampir seluruh bagian dari tanaman sorgum seperti biji, tangkai biji, daun, batang dan akar dapat dimanfaatkan. Sorgum sudah dikembangkan dengan bantuan teknik radiasi yakni menghasilkan sorgum var. Samurai 2 . Sorgum jenis ini cocok digunakan sebagai pakan bagi hewan ternak [5,6]. Hasil pengujian secara in vitro menunjukkan bahwa daun, batang dan bagas sorgum var. Samurai 2 dapat digunakan untuk pakan ternak [7], sedangkan pengujian secara in vivo dengan menggunakan bagas sorgum manis dapat meningkatkan produktivitas kerbau [8].

Silase dapat dinaikkan kualitasnya dengan menambahkan probiotik selama proses fermentasi [1]. Probiotik yang digunakan pada penelitian ini adalah BIOS $\mathrm{K} 2$ yang mengandung isolat khamir. BIOS K2 merupakan salah satu suplemen yang diproduksi oleh BATAN yaitu suplemen yang mengandung mikroba dari jenis khamir. Pemberian probiotik ini dapat menstabilkan $\mathrm{pH}$ cairan rumen, meningkatkan kecernaan dan nutrisi, menekan produksi amonia, dan menghasilkan faktor pertumbuhan untuk bakteri pendegradasi serat [3]. Probiotik BIOS K2 hanya diberikan saat pembuatan 
bibit silase sinambung yang diinkubasi selama 21 hari. Silase sorgum yang mengandung probiotik BIOS K2 menunjukkan mampu meningkatkan kinerja mikroba rumen secara in vitro [4].

Berdasarkan uraian di atas maka tujuan dari penelitian ini adalah untuk mengevaluasi silase sinambung hijauan sorgum varietas Samurai 2 yang mengandung probiotik BIOS $\mathrm{K} 2$ secara in vitro dengan menggunakan cairan rumen kerbau. Adapun waktu inkubasi silase sinambung yang digunakan adalah 3 dan 7 hari dengan pembanding silase yang diinkubasi 21 hari. Diharapkan dari penelitian ini diperoleh informasi mengenai potensi silase sinambung sorgum sebagai pakan ternak ruminansia.

\section{BAHAN DAN METODE}

\section{Alat dan Bahan}

Alat-alat utama yang digunakan adalah alat-alat gelas, sentrifus, $\mathrm{pH}$ meter, oven, desikator, timbangan, tanur, cawan porselen, cawan masir, pompa vakum, refluks, soklet, sonikator, cawan Conway, syringe, buret, water bath shaker dan destilator. Bahan-bahan utama yang digunakan adalah cairan rumen, serbuk bibit silase sorgum hari ke-21 (A) untuk bibit silase sinambung, silase sinambung sorgum hari ke-3 (B), dan silase sinambung sorgum hari ke-7 (C) dan larutan Mc Dougall serta cairan rumen kerbau.

\section{Analisis Kandungan Nutrisi Pakan}

Pakan percobaan yang terdiri dari silase sorgum, silase sinambung sorgum hari ke-3 dan silase sinambung sorgum hari ke-7 dianalisis kandungan nutrisinya yang terdiri dari bahan kering, bahan organik, serat kasar, lemak kasar, protein kasar dan neutral detergent fibre (NDF) [9].

\section{Uji InVitro}

Uji in vitro dilakukan dengan teknik Hohenheim Gas Test [10]. Perlakuan terdiri dari cairan rumen yang ditambahkan serbuk bibit silase sinambung (A), silase sinambung hari ke-3 (B), dan silase sinambung hari ke-7 (C) dengan ulangan 4 kali. Data dianalisis dengan menggunakan rancangan acak lengkap (RAL).

Sampel perlakuan dengan berat 200 mg dimasukkan ke dalam syringe dan ditambah $30 \mathrm{ml}$ larutan Mc Dougall yang mengandung cairan rumen. Untuk menjaga suasana tetap anaerob, larutan tersebut disuplai gas $\mathrm{CO}_{2}$. Kemudian diinkubasi menggunakan waterbath suhu $39^{\circ} \mathrm{C}$. Pengamatan produksi gas dilakukan pada jam ke-0, 2, 4, 8, 12, dan 24, sedangkan nilai $\mathrm{pH}$, konsentrasi amonia [11], konsentrasi volatile fatty acids (VFA) [12], degradasi bahan kering (\%DBK), degradasi bahan organik (\%DBO), degradasi serat kasar (\%DSK) [13] dan sintesis protein mikroba (bakteri dan protozoa) dengan menggunakan radioisotop P-32 secara in vitro [14] serta konsentrasi gas metana dan karbondioksida [15], dilakukan pada jam ke-24.

\section{HASIL DAN PEMBAHASAN}

\section{Kandungan Nutrisi Pakan Percobaan}

Hasil analisis setiap sampel menunjukkan bahwa sampel A (silase sorgum Samurai 2) memiliki nilai tertinggi pada nilai $\mathrm{BK}, \mathrm{BO}, \mathrm{SK}$, dan $\mathrm{PK}$ dibandingkan dengan sampel $\mathrm{B}$ (silase sinambung hari ke3) dan C (silase sinambung hari ke-7) (Tabel 1). Hal ini menandakan bahwa sorgum Samurai 2 yang dijadikan silase dalam waktu 21 hari (A) memiliki kualitas lebih baik dibandingkan dengan sampel $\mathrm{B}$ dan sampel C. Waktu inkubasi yang hanya 3 dan 7 hari serta pemberian bibit silase yang hanya $10 \%$ menjadi penyebab kualitas pakan B dan C lebih rendah dari A.

Hasil analisis statistik menunjukkan tidak ada pengaruh nyata perlakuan terhadap kandungan bahan kering, bahan organik dan NDF, sedangkan pada kandungan serat kasar, lemak kasar dan protein kasar sebaliknya. Serat kasar pada sampel A lebih tinggi dibandingkan dengan sampel B dan C karena waktu inkubasi yang 
lebih lama menyebabkan terurainya senyawa organik sederhana menjadi gas dan berkurangnya air karena digunakan saat hidrolisis senyawa organik [16]. Serat kasar pada ternak ruminansia digunakan sebagai sumber energi utama. Komponen yang terkandung dalam serat kasar antara lain selulosa, hemiselulosa, dan lignin [17]. menyusun protein mikroba [18]. Pengukuran protein kasar pada sampel bertujuan untuk mengetahui jumlah protein pada pakan dan sampel A (silase sorgum Samurai 2) menunjukkan bahwa protein kasar yang terkandung dalam pakan A lebih tinggi dibandingkan kedua sampel lainnya.

Tabel 1.Kandungan nutrisi $(\%)$ pakan silase dan silase sinambung.

\begin{tabular}{cccc}
\hline Proksimat & \multicolumn{3}{c}{ Sampel } \\
& $\mathrm{A}$ & $\mathrm{B}$ & $\mathrm{C}$ \\
\hline Bahan kering & $91.29^{\mathrm{a}}$ & $89.34^{\mathrm{a}}$ & $89.7^{\mathrm{a}}$ \\
Bahan organik & $88.02^{\mathrm{a}}$ & $87.84^{\mathrm{a}}$ & $87.5^{\mathrm{a}}$ \\
Serat kasar & $64.57^{\mathrm{a}}$ & $54.77^{\mathrm{b}}$ & $54.3^{\mathrm{b}}$ \\
Lemak kasar & $0.86^{\mathrm{a}}$ & $0.6^{\mathrm{b}}$ & $1.45^{\mathrm{c}}$ \\
Protein kasar & $18.46^{\mathrm{a}}$ & $17.83^{\mathrm{b}}$ & $18.65^{\mathrm{a}}$ \\
Neutral detergent fibre & $68.16^{\mathrm{a}}$ & $69.45^{\mathrm{a}}$ & $69.92^{\mathrm{a}}$ \\
\hline
\end{tabular}

Keterangan: Superskrip yang berbeda menunjukkan perbedaan nyata $(\mathrm{p} \leq 0.05)$; A (silase sorgum Samurai 2), B (silase sinambung 3 hari sorgum Samurai 2) dan C (silase sinambung 7 hari sorgum Samurai 2).

Adanya penambahan probiotik BIOS K2 dapat membantu proses degradasi senyawa organik karena membuat kondisi menjadi lebih asam dengan dihasilkannya senyawa asam laktat dan dihasilkannya senyawa pendukung pertumbuhan bakteri seperti vitamin B1 [1].

Perbedaaan kandungan lemak kasar setiap sampel dipengaruhi oleh waktu inkubasi yang menyebabkan jumlah dan dinamika populasi mikroba yang berbeda. Lemak berguna untuk ternak sebagai energi dalam melakukan metabolisme tubuh [17]. Meningkatnya kandungan lemak kasar menunjukkan adanya penguraian karbohidrat pada saat proses fermentasi dapat menghasilkan asam-asam lemak. Protein kasar memiliki peranan penting di dalam rumen, karena protein kasar akan mengalami proses hidrolisis menjadi peptida oleh enzim proteolisis yang dihasilkan oleh mikroba proteolitik. Peptida akan mengalami degradasi lebih lanjut menjadi asam-asam amino yang nantinya akan dideaminasi menjadi ammonia untuk

\section{Derajat Keasaman $(\mathbf{p H})$}

Derajat keasaman $(\mathrm{pH})$ pada setiap sampel perlakuan menunjukkan hasil yang berbeda pada awal inkubasi. Perlakuan A, B dan $C$ memiliki nilai sebesar 7,$16 ; 7,14$; dan 6,96 (Gambar 1). Perbedaan terjadi karena sampel pakan yang digunakan berupa silase dengan waktu inkubasi berbeda. Setelah itu mengalami penurunan dengan nilai yang berbeda setelah inkubasi 24 jam. Penurunan $\mathrm{pH}$ tertinggi terjadi pada sampel silase sinambung yang diinkubasi 7 hari (C) sebesar 0,73, sedangkan sampel silase sorghum bibit (A) dan silase sinambung yang diinkubasi 3 hari hanya 0,62 dan 0,67. Hasil statistik menunjukkan bahwa perlakuan mempengaruhi nilai $\mathrm{pH}$ cairan rumen setiap perlakuan $(\mathrm{p} \leq 0,05)$. Hasil uji lanjut Duncan menunjukkan bahwa perubahan nilai $\mathrm{pH}$ semua perlakuan berbeda nyata. Adanya probiotik BIOS K2 menjadi salah satu penyebab penurunan nilai $\mathrm{pH}$ cairan rumen, karena khamir yang dikandungnya menghasilkan senyawa- 


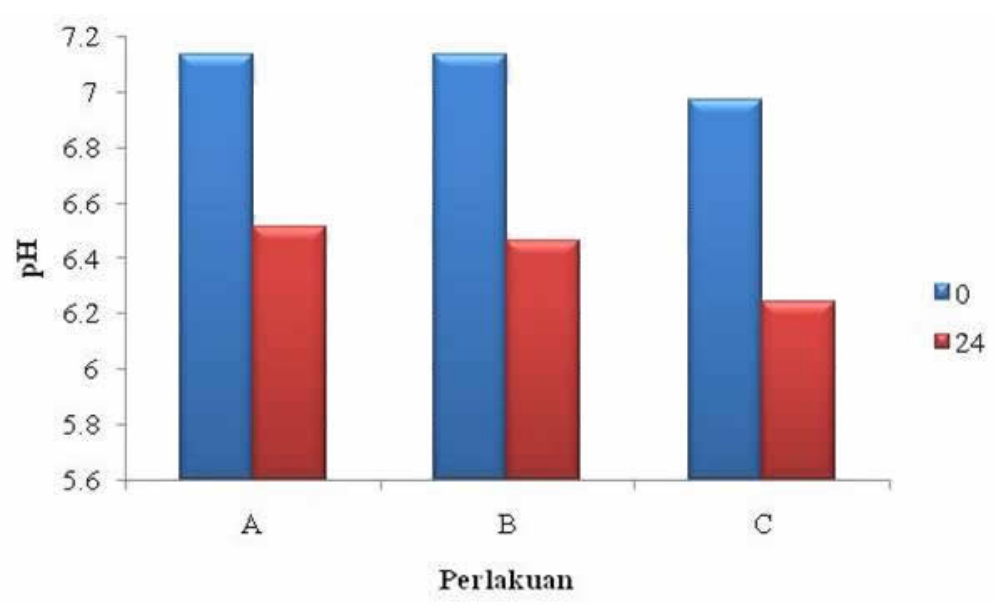

Gambar 1. Derajat keasamaan (pH) pada jam ke-0 dan 24 perlakuan A (silase sorgum Samurai 2), B (silase sinambung 3 hari sorgum Samurai 2) dan C (silase sinambung 7 hari sorgum Samurai 2) dalam cairan rumen kerbau.

senyawa yang bersifat asam seperti asam laktat [3].

Nilai $\mathrm{pH}$ merupakan salah satu faktor yang mendukung keberhasilan dari proses fermentasi [20]. Nilai $\mathrm{pH}$ yang dihasilkan semua sampel perlakuan masih dalam kisaran $\mathrm{pH}$ normal untuk aktivitas mikroba cairan rumen, yaitu sebesar 5,5 - 7,5. Mikroba di dalam rumen tidak akan bekerja dengan baik dalam melakukan proses pencernaan apabila tidak berada pada $\mathrm{pH}$ yang optimum untuk kelangsungan hidupnya [20].

Perubahan $\mathrm{pH}$ ini menunjukkan aktivitas metabolisme mikroorganisme dalam melakukan fermentasi bahan pakan [5]. Hal ini dapat dilihat dari pengamatan foto mikroba yang menggambarkan adanya bakteri, protozoa, dan khamir pada setiap sampel. Hasil fermentasi di dalam rumen

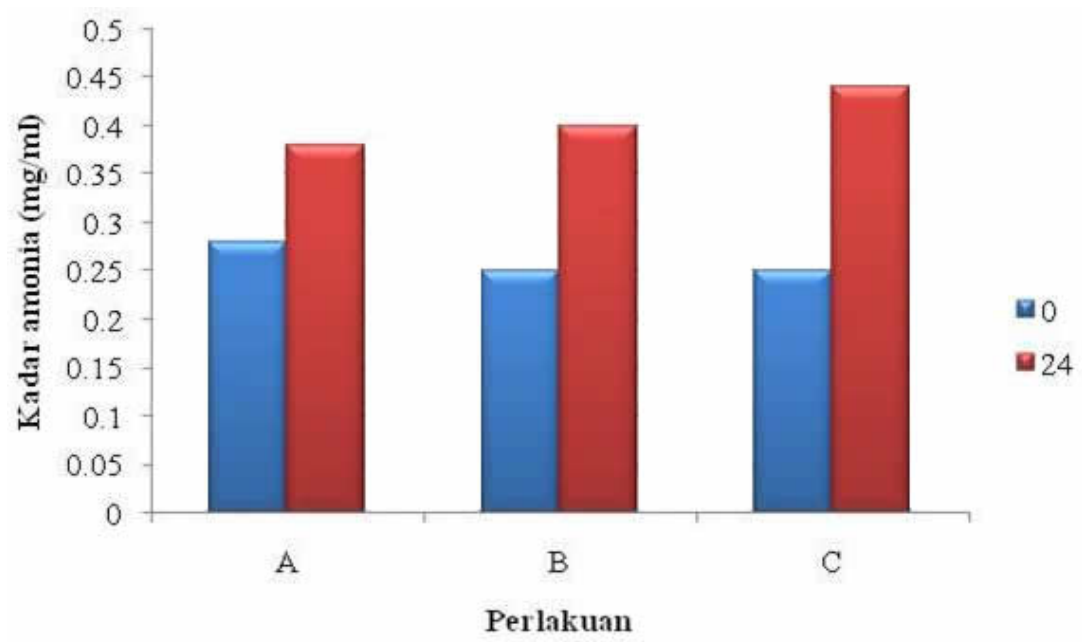

Gambar 2. Konsentrasi amonia pada jam ke-0 dan 24 perlakuan A (silase sorgum Samurai 2), B (silase sinambung 3 hari sorgum Samurai 2) dan C (silase sinambung 7 hari sorgum Samurai 2) dalam cairan rumen kerbau. 
yang berupa VFA akan menyebabkan penurunan $\mathrm{pH}$ rumen. VFA dihasilkan dari khamir yang berada di dalam probiotik melakukan degradasi senyawa organik dari pakan seperti selulosa, hemiselulosa, dan lignin lebih tinggi dan akan menghasilkan produk berupa asam-asam organik seperti VFA. Khamir di dalam rumen akan mengubah kondisi awal aerob menjadi anaerob, dimana keadaan ini akan mendukung viabilitas mikroba rumen dalam melakukan fermentasi lebih tinggi [3].

\section{Amonia}

Konsentrasi amonia pada setiap sampel mengalami kenaikan setelah inkubasi 24 jam (Gambar 2). Kenaikan tertinggi terjadi pada

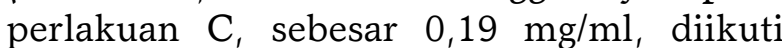
dengan perlakuan $\mathrm{B}$ dan $\mathrm{A}$, sebesar 0,15 dan $0,10 \mathrm{mg} / \mathrm{ml}$. Akan tetapi, secara statistik tidak ada pengaruh perlakuan terhadap konsentrasi ammonia $(\mathrm{p} \geq 0,05)$.

Amonia adalah salah satu produk fermentasi di dalam rumen yang berasal dari degradasi protein yang nantinya akan digunakan oleh mikroba rumen untuk pertumbuhannya [19]. Mikroba rumen akan memanfaatkan amonia sebagai sumber nitrogen terbesar yang digunakan dalam sintesis protein. Protein yang dihasilkan dapat berperan sebagai protein struktural dalam pembentukan komponen sel dan fungsional dalam bentuk enzim [21].

Konsentrasi amonia pada rumen memiliki hubungan dengan nilai $\mathrm{pH}$, namun pada penelitian kali ini konsentrasi amonia tidak sesuai dengan nilai $\mathrm{pH}$. Konsentrasi amonia mengalami kenaikan, sedangkan nilai $\mathrm{pH}$ mengalami penurunan (Gambar 1). Hal ini terjadi karena konsentrasi amonia yang dihasilkan lebih rendah dibandingkan senyawa-senyawa asam organik yang dihasilkan seperti VFA [14]. Adanya penambahan probiotik BIOS K2 yang mengandung khamir akan menyebabkan nilai $\mathrm{pH}$ lebih asam [3]. Selain itu, khamir dapat menurunkan konsentrasi amonia, karena khamir memiliki kemampuan untuk menunjang pertumbuhan bakteri sehingga amonia yang dihasilkan oleh mikroba lain akan digunakan oleh mikroba selulolitik atau asetogenik untuk pertumbuhannya [1].

\section{Volatile Fatty Acids(VFA)}

Konsentrasi VFA cairan rumen setiap perlakuan mengalami kenaikan setelah inkubasi 24 jam dan memiliki nilai yang berbeda (Gambar 3). Kenaikan tertinggi terjadi pada perlakuan $\mathrm{C}$ sebesar 0,59 $\mathrm{mg} / \mathrm{ml}$, diikuti dengan perlakuan $\mathrm{B}$ dan $\mathrm{A}$, sebesar 0,40 dan $0,28 \mathrm{mg} / \mathrm{ml}$. Hal ini kemungkinan karena mikroba cairan rumen lebih mudah untuk mengurai senyawasenyawa organik sederhana hasil penguraian hijauan sorghum oleh mikroba dari bibit silase yang telah teradaptasi (dari sampel A) dan pengaruh dari waktu inkubasi yang lebih lama, yaitu 7 hari (C). Hasil analisis statistik pun menunjukkan bahwa perlakuan mempengaruhi konsentrasi VFA $(p \leq 0,05)$. Hasil uji lanjut menunjukkan bahwa perubahan nilai VFA semua perlakuan berbeda nyata.

VFA adalah sumber energi yang digunakan ternak ruminansia dan merupakan hasil dari proses fermentasi pakan di dalam rumen. Energi yang dihasilkan akan dimanfaatkan oleh ternak dan menunjang kehidupan dari mikroba rumen [20]. Kenaikan nilai VFA dapat dipengaruhi oleh pemberian probiotik khamir [1]. Selain itu, nilai VFA dapat dikaitkan dengan nilai $\mathrm{pH}$ pada rumen. Proses fermentasi yang berjalan secara terus menerus akan menghasilkan VFA dengan jumlah yang besar sehingga $\mathrm{pH}$ akan mengalami penurunan (Gambar 1), sedangkan VFA hasil fermentasi berada dalam jumlah yang rendah maka $\mathrm{pH}$ akan mengalami kenaikan [20]. Hal ini dapat terlihat dari hasil pengukuran konsentrasi VFA pada sampel yang sebanding dengan penurunan nilai $\mathrm{pH}$ (Gambar 1). Konsentrasi amonia yang mengalami kenaikan tidak mempengaruhi nilai $\mathrm{pH}$ (Gambar 2).

Kenaikan pada nilai VFA menunjukkan terjadinya fermentasi senyawa kompleks yakni karbohidrat (serat kasar) menjadi VFA. Komponen serat kasar bermacam-macam salah satunya yakni 


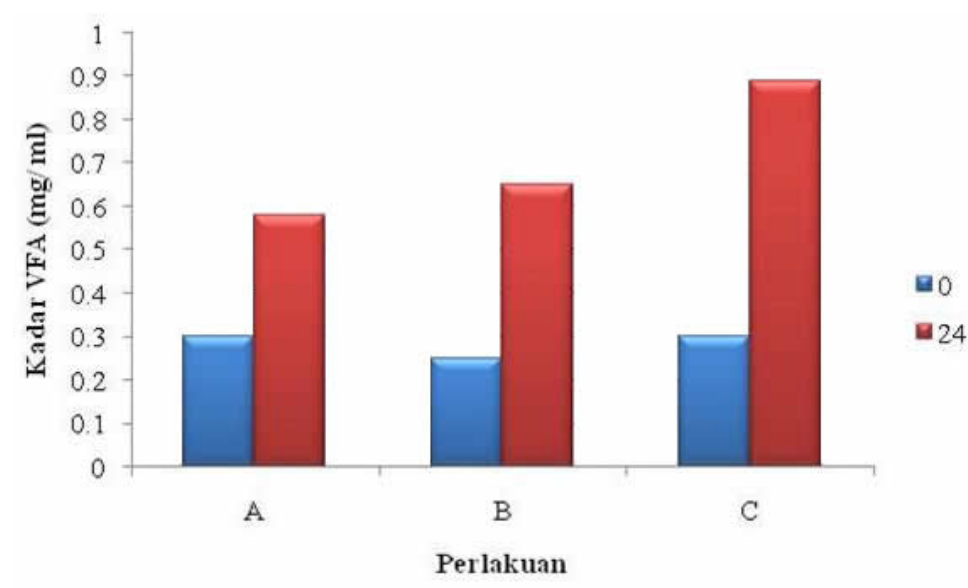

Gambar 3. Konsentrasi VFA total pada jam ke-0 dan 24 perlakuan A (silase sorgum Samurai 2), B (silase sinambung 3 hari sorgum Samurai 2) dan C (silase sinambung 7 hari sorgum Samurai 2) dalam cairan rumen kerbau.

selulosa. Selulosa akan didegradasi oleh enzim selulase untuk menghasilkan selobiosa yang nantinya akan dipecah menjadi gula-gula sederhana. Gula-gula sederhana ini akan mengalami proses glikolisis menjadi asam piruvat melalui oksidasi glukosa secara anaerob. Asam piruvat kemudian diubah menjadi VFA berupa asetat, propionat dan butirat. Selain itu juga menghasilkan $\mathrm{H}_{2} \mathrm{O}, \mathrm{CO}_{2}$ dan $\mathrm{CH}_{4}$. VFA nantinya akan diserap oleh dinding rumen yang digunakan sebagai sumber karbon [22].

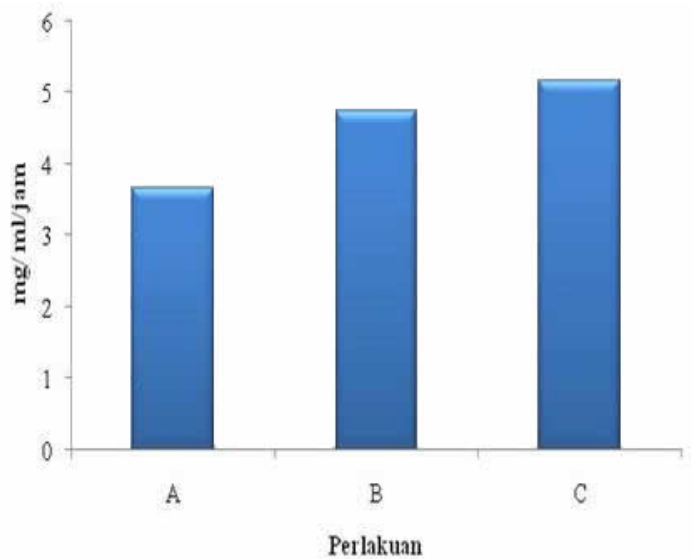

\section{Sintesis Protein Mikroba}

Sintesis protein mikroba (bakteri dan protozoa) menunjukkan hasil yang berbeda pada setiap sampel (Gambar 4). Sintesis protein bakteri sampel $\mathrm{C}$ memiliki nilai tertinggi yakni $5,18 \mathrm{mg} / \mathrm{ml} / \mathrm{jam}$, sedangkan pada sampel A dan B sebesar 3,67 dan 4,76 $\mathrm{mg} / \mathrm{ml} / \mathrm{jam}$. Hasil berbeda terjadi pada sintesis protein protozoa, dimana sampel A dan B memiliki nilai yang sama yakni 2,62 $\mathrm{mg} / \mathrm{ml} / \mathrm{jam}$ lebih tinggi dibandingkan perlakuan $\mathrm{C}$ sebesar $2,55 \mathrm{mg} / \mathrm{ml} / \mathrm{jam}$. Hasil analisis statistik menunjukkan bahwa

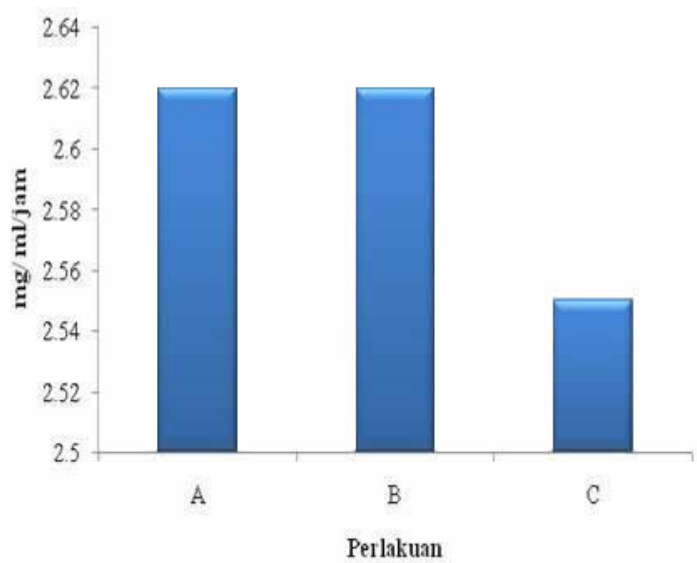

Gambar 4. Sintesis protein bakteri (kiri) dan protozoa (kanan) perlakuan A (silase sorgum Samurai 2), B (silase sinambung 3 hari sorgum Samurai 2) dan C (silase sinambung 7 hari sorgum Samurai 2) dalam cairan rumen kerbau setelah 24 jam inkubasi. 
sintesis protein mikroba dipengaruhi oleh sampel perlakuan $(p \leq 0,05)$. Hasil uji lanjut menunjukkan bahwa sintesis protein bakteri perlakuan A berbeda nyata terhadap perlakuan B dan $\mathrm{C}$, sedangkan sintesis protein protozoa berbeda nyata untuk perlakuan $\mathrm{C}$ terhadap perlakuan A dan B.

Peningkatan sintesis protein bakteri menunjukkan bahwa terjadi pertumbuhan bakteri rumen dalam memanfaatkan sampel silase semua perlakuan yang ditunjukkan dengan besarnya nilai inkorporasi radioisotop P-32. Hasil ini sebanding dengan produksi amonia dan VFA dari setiap perlakuan (Gambar 2 dan 3) yang protozoa tidak cocok untuk hidup dalam kondisi $\mathrm{pH}$ rendah.

\section{Degradasi Bahan Kering dan Bahan Organik (\%DBK dan \%DBO)}

Degradasi bahan kering (\%DBK) dan degradasi bahan organik (\%DBO) pada setiap sampel memiliki nilai yang berbeda setelah 24 jam inkubasi (Gambar 5). \%DBK dan DBO sampel A (silase sorgum Samurai 2) memiliki nilai tertinggi dibandingkan dengan sampel yang lain yakni sebesar 46,04 dam $47,30 \%$, diikuti dengan sampel $\mathrm{C}$ dan $\mathrm{B}$ sebesar 36,25 dan 37,15\%; 22,25 dan $25,18 \%$. Hasil analisis statistik menunjukkan

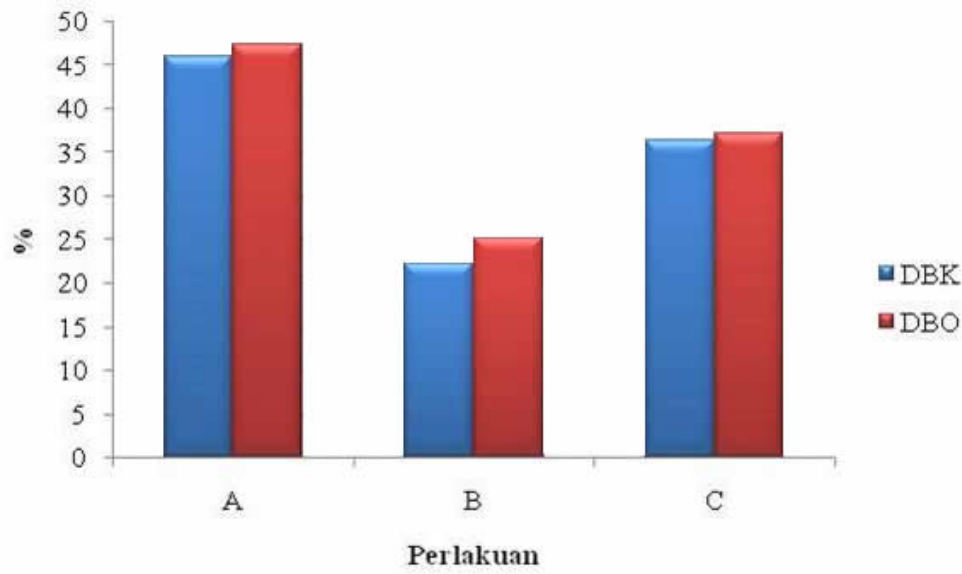

Gambar 5. Degradasi Bahan Kering (\%DBK) dan Degradasi Bahan Organik (\%DBO) perlakuan A (silase sorgum Samurai 2), B (silase sinambung 3 hari sorgum Samurai 2) dan C (silase sinambung 7 hari sorgum Samurai 2) dalam cairan rumen kerbau setelah 24 jam inkubasi.

menunjukkan konsentrasi tertinggi terjadi pada perlakuan C. Sintesis protein mikroba dapat dikaitkan dengan konsentrasi amonia, dimana amonia merupakan sumber nitrogen yang digunakan untuk sintesis protein. Nilai amonia yang rendah menunjukkan pemanfaatan amonia sebagai sumber nitrogen untuk pertumbuhan mikroba rumen [20]. Rendahnya nilai $\mathrm{pH}$ pada perlakuan $\mathrm{C}$ menyebabkan sintesis protein protozoa mengalami penurunan karena bahwa \%DBK dan \%DBO dipengaruhi oleh sampel perlakuan $(p \leq 0,05)$ dan berbeda nyata untuk semua perlakuan.

Perbedaan nilai \%DBK dan \%DBO pada setiap sampel dapat dipengaruhi oleh pemanfaatan bahan kering (BK) dan bahan organik (BO) oleh mikroba cairan rumen untuk pertumbuhan selama proses fermentasi. Tingginya tingkat degradasi pada sampel A karena pengaruh lamanya inkubasi selama 21 hari yang memungkinkan senyawa organik sederhana 
terakumulasi banyak sehingga memudahkan proses degradasi oleh mikroba cairan rumen. \%DBO yang tinggi pada perlakuan $\mathrm{A}$ tidak diikuti dengan produksi amonia dan VFA serta sintesis protein mikroba yang tinggi pula (Gambar3). Hal ini kemungkinan karena produk akhir yang banyak dihasilkan berupa gas.

Selain itu, degradasi sampel dipengaruhi pula oleh keberadaan khamir yang terdapat pada probiotik BIOS K2, karena produk sampingnya seperti vitamin B3 dapat meningkatkan populasi bakteri selulotik dan asetogenik dalam mendegradasi bahan organik [3]. Sampel B $(\mathrm{p} \geq 0,05)$. Produksi gas yang dihasilkan tidak sesuai dengan nilai \% DBK dan DBO perlakuan (Gambar 5).

Seharusnya produksi gas tertinggi dihasilkan oleh perlakuan A dengan perbedaan yang signifikan dibandingkan perlakuan B dan C. Kemungkinan, produk metabolisme yang dihasilkan mikroba cairan rumen tidak berakhir dalam bentuk gas tetapi menjadi biomassa. Dalam hal ini, khusus untuk perlakuan A menjadi biomassa protozoa (Gambar 4). Kenaikan produksi gas ini disebabkan oleh aktivitas mikroba di dalam rumen selama proses fermentasi dalam mendegradasi pakan yang

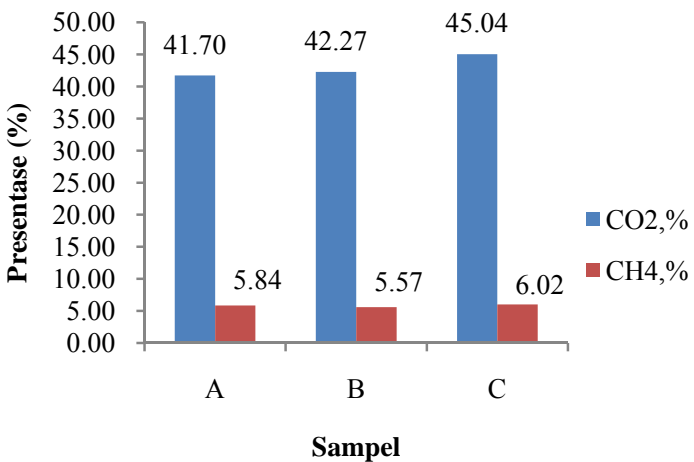

Gambar 6. Produksi gas dan konsentrasi gas $\mathrm{CO}_{2}$ dan $\mathrm{CH}_{4}$ perlakuan A (silase sorgum Samurai 2), B (silase sinambung 3 hari sorgum Samurai 2), dan C (silase sinambung 7 hari sorgum Samurai 2) dalam cairan rumen kerbau.

yang memiliki nilai \%DBK dan \%DBO terendah dapat disebabkan keberadaan mikroba rumen yang tidak dapat memanfaatkan bahan organik secara maksimal untuk pertumbuhan. Hal ini, dapat pula disebabkan beberapa faktor seperti kurang terpenuhinya waktu fermentasi karbohidrat mudah larut, kurangnya unsur nitrogen, serta keberadaan tanin pada pakan [22].

\section{Produksi Gas Secara In Vitro}

Produksi gas pada semua sampel perlakuan memiliki pola yang sama selama 24 jam inkubasi (Gambar 6). Hasil analisis statistik menunjukkan bahwa semua sampel perlakuan tidak mempengaruhi produksi gas berujung pada dihasilkannya gas seperti $\mathrm{CO}_{2}$ dan $\mathrm{CH}_{4}$. Produk gas yang tinggi menunjukkan bahwa banyak energi yang tidak dapat digunakan oleh mikroba untuk memenuhi kebutuhan nutrisi ternak [22].

Hasil analisis gas $\mathrm{CO}_{2}$ dan $\mathrm{CH}_{4}$ menunjukkan nilai yang berbeda untuk semua sampel perlakuan $(\mathrm{p} \leq 0,05)$. Hasil analisis statistik menunjukkan bahwa konsentrasi gas $\mathrm{CO}_{2}$ dan $\mathrm{CH}_{4}$ dipengaruhi oleh sampel perlakuan $(p \leq 0,05)$. Hasil uji lanjut menunjukkan bahwa konsentrasi gas $\mathrm{CO}_{2}$ perlakuan A dan B tidak berbeda nyata, sedangkan untuk konsentrasi gas $\mathrm{CH}_{4}$, semua perlakuan berbeda nyata. Konsentrasi gas $\mathrm{CO}_{2}$ pada sampel $\mathrm{A}, \mathrm{B}$ dan $\mathrm{C}$ sebesar 41,70 ; $42,27 \%$; dan 45,04. Konsentrasi gas 
$\mathrm{CH}_{4}$ yang dihasilkan pada perlakuan sampel A, B dan C sebesar 5,84; 5,57; dan 6,02\%. Gas yang dihasilkan dari fermentasi pakan secara langsung yakni $\mathrm{CO}_{2}$ dan $\mathrm{CH}_{4}$ yang berasal dari VFA. Gas $\mathrm{CH}_{4}$ merupakan hasil dari fermentasi karbohidrat yang dilakukan oleh bakteri penghasil metanogenik. Komposisi gas di dalam rumen berkisar $65 \%$ untuk $\mathrm{CO}_{2}$ dan $27 \%$ untuk $\mathrm{CH}_{4}$ [2]. Hasil ini berbeda, karena adanya penambahan probiotik BIOS K2 yang memiliki kemampuan menghambat produksi gas metana melalui penekanan pertumbuhan protozoa. Protozoa merupakan inang dari bakteri metanogen [23].

\section{KESIMPULAN}

Pakan silase sinambung sorgum Samurai 2 dengan lama inkubasi selama 7 hari (C) memiliki kualitas yang lebih baik dibandingkan dengan silase sorgum yang diinkubasi 21 hari atau bibit (A) dan silase sinambung yang diinkubasi 3 hari (B).

\section{UCAPAN TERIMA KASIH}

Penulis mengucapkan terima kasih kepada pihak PAIR-BATAN yang telah memfasilitasi penulis dalam melakukan penelitian ini.

\section{DAFTAR PUSTAKA}

1. SUGORO, I, Pemanfaatan Probiotik Khamir untuk Peningkatan Produksi Ternak Ruminansia. Iptek Nuklir Bunga Rampai Presentasi Ilmiah Peneliti Madya/Utama, 1 (1), 253-314 (2010).

2. TITTERTON, M. BAREEBA, F.B., Grass and Legume Silages in The Tropics, FAO Electronic Confrence on Tropical Silage, 1, 116 (2008).
3. SUGORO, I, Aplikasi Silase Sinambung Hijauan Pakan Ternak Ruminansia di Nusa Penida Bali, Laporan Penelitian Spesifik Lokasi, RISTEK (2010).

4. SUGORO, I., N. KAMILA, D. ELFIDASARI, Degradasi Sorghum pada Rumen Kerbau dengan Suplemetasi Probiotik BIOS K2 secara In Sacco, J. Ilmiah Aplikasi Isotop dan Radiasi, 10 (2), 103-111 (2014).

5. SIHONO, et.al., Galur Mutan Sorgum PATIR-1 Berdaya Hasil Biji, Biomasa dan Gula Batang Tinggi serta Galur PATIR-4 Hasil Biji Tinggi Kualitas Baik, Proposal Pelepasan Varietas, Pusat Aplikasi Isotop dan Radiasi, BATAN (2013).

6. SOERANTO, Pemuliaan Tanaman Sorgum.

http://batan.go.id/patir/pert.html[1 4 Agustus 2015 (2005).

7. WAHYONO T., D.A. ASTUTI, K.G. WIRYAWAN, I. SUGORO, Pengujian Ransum Kerbau Berbahan Baku Sorghum sebagai Sumber Serat secara In Vitro dan In Sacco, J. Ilmiah Aplikasi Isotop dan Radiasi, 10 (2), 98-106 (2014).

8. SESHAIAH CV, S.J. RAO, Y.R. REDDY, M. MAHENDAR, M.K. KUMAR, Effect of Feeding Differently Processed Sweet Sorghum Bagasse Based Complete Rations on Feeding Behaviour, Milk Production and Cost Economics in Graded Murrah Buffaloes, Buffalo Bull, 32 (3), 231-238 (2013).

9. CHERNEY, D.J.R. Characterization of Forage by Chemical Analysis, In : Given, D. I., I. Owen., R. F. E. Axford., and H. M. Omed. Forage Evaluation in Ruminant Nutrition, 
Wollingford: CABI Publishing, 281-300 (2000).

10. BLUMMEL, M., H. STEINGASS, K. BECKER, The Relationship Between In Vitro Gas Production, In Vitro Microbial Biomass Yield and N-15 Incorporation and Its Applications for The Prediction of Voluntary Feed Intake of Roughages, Bri. J. Nutr., 77, 911921 (1997).

11. WIDODO, WAHYONO, F., SUTRISNO, Kecernaan Bahan Kering, Kecernaan Bahan Organik, Produksi VFA dan $\mathrm{NH}_{3}$ Pakan Komplit dengan Level Jerami Padi secara In Vitro, J. Animal Agriculture, 1 (1), 215-230 (2012).

12. LUTZHOFT, H.C.H, I. ANGELIDAKI, K. BOE, Comparison of VFA Titration Procedures Used for Monitoring The Biogas Process, Water Research, 54, 262-272 (2014).

13. VAN SOEST, P.J., J.B. ROBERTSON, B.A. LEWIS, Methods for Dietary Fiber Neutral Detergent Fiber andNon-starch Polysaccharides in Relation to Annual Nutrition, J. Dairy Sci., 74, 3583-3597 (1991).

14. HENDRATNO, C., Penggunaan ${ }^{32} \mathrm{P}$ dan ${ }^{35} \mathrm{~S}$ sebagai Penanda pada Pengukuran Pembentukan Masa Mikroba Rumen Kerbau, Risalah Pertemuan Ilmiah Aplikasi Teknik Nuklir di Bidang Pertanian dan Peternakan, 479-491 (1985).

15. SUGORO. I. K.G. WIRYAWAN, D.A. ASTUTI, T. WAHYONO, Gas Production and Rumen Fermentation Characteristics of Buffalo Diets, JITV, 20 (4), 242249 (2015).
16. FAYYAZ A.S., Q. MAHMOOD, M. M. SHAH, A. PERVEZ, AND S.A. ASAD, Review Article : Microbial Ecology of Anaerobic Digesters: The Key Players of Anaerobiosis, Scientific World Journal, Hindawi Publishing Corporation, $1-21$, (2014).

17. HENDRANINGSIH L. Nilai Kecernaan Serat Kasar dan Produksi Gas Jerami Padi (Secara In Vitro) dengan Introduksi Bakteri Selulolitik, Jurnal Agrovet, Universitas Airlangga, (2010).

18. SUPRAPTO H, SUHARTATI FM, dan WIDYASTUTI T, Kecernaan Serat Kasar dan Lemak Kasar Complete Feed Limbah Rami dengan Sumber Protein Berbeda pada Kambing Peranakan Etawa Lepas Sapih, J. Ilmiah Peternakan, 1 (3), 938-946. (2013).

19. NUSWANTARA, L.K., Ilmu Makanan Ternak Ruminansia, Semarang: Fakultas Peternakan, Universitas Diponogoro, 105-106 (2002).

20. SRETENOVIĆ LJ., M. P. PETROVIĆ, S. ALEKSIĆ, V. PANTELIĆ, V. KATIĆ, V. BOGDANOVIĆ, R. BESKOROVAJNI, Influence of Yeast, Probiotics and Enzymes in Rations On Dairy Cows Performances During Transition, Biotechnology in Animal Husbandry, 24 (5-6), 33-43 (2008).

21. MC DONALD, P., R. EDWARDS, and J. GREENHALGH, Animal Nutrition. $6^{\text {th }}$ Edition, New York, 202-211 (2002).

22. KRISHNAMOORTHY, U., RCA Training Workshop on In Vitro Techniques for Feed Evaluation, The International Atomic Energy 
Relationship Between Rumen Methanogens and Methane Production in Dairy Cows Fed 23. ZHOU, M., Y. H. CHUNG, K. A. BEAUCHEMIN, L. HOLTSHAUSEN, M. OBA, T. A. MCALLISTER and L.L. GUAN,
Diets Supplemented with a Feed

Enzyme Additive. Journal of Applied Microbiology 111: 11481158 (2011). 